\title{
The Met tyrosine kinase receptor as a therapeutic target and a potential cancer stem cell factor responsible for therapy resistance (Review)
}

\author{
KATARZYNA MIEKUS \\ Department of General Biochemistry, Faculty of Biochemistry, Biophysics and Biotechnology, \\ Jagiellonian University, 30-387 Cracow, Poland
}

Received July 6, 2016; Accepted November 17, 2016

DOI: $10.3892 /$ or.2016.5297

\begin{abstract}
The MET tyrosine kinase receptor plays an important role during tumor development and progression being responsible for proliferation, morphogenetic transformation, cell motility and invasiveness. High expression of the MET receptor has been shown to correlate with increased tumor growth and metastasis, poor prognosis and resistance to radiotherapy. Moreover, MET expression and activation has been shown to be associated with therapy resistance. The occurrence of resistance to targeted therapy might be related to the presence of cancer stem cells (CSCs). CSCs are a subpopulation of cells in the tumor that possess the ability of self-renewal, clonogenicity, radioresistance and self-sustained protection from apoptosis. Recently, MET has been postulated as an essential factor supporting the functional stem cell phenotype in some tumors and as a CSC factor is believed to be responsible for therapy resistance. This review presents the results from recent studies identifying MET as a potential marker of CSCs and tumor initiating cells, demonstrating pivotal role of MET in supporting stem cell phenotype and indicating the role of MET in acquiring resistance to antitumor therapy.
\end{abstract}

Correspondence to: Dr Katarzyna Miekus, Department of General Biochemistry, Faculty of Biochemistry, Biophysics and Biotechnology, Jagiellonian University, Gronostajowa Street 7, 30-387 Cracow, Poland

E-mail: katarzyna.miekus@uj.edu.pl

Abbreviations: AML, acute myeloid leukemia; CCIC, colorectal cancer initiating cells; CICs, cancer-initiating cells; CSCs, cancer stem cells; EGFR, epidermal growth factor receptor; GBM, glioblastoma multiforme; GSCs, glioblastoma stem cells; HER, human epidermal receptor; HGF, hepatocyte growth factor; HNSCC, human head and neck squamous cell carcinoma; NOD/SCID, non-obese diabetic/severe combined immunodeficiency; NSCLC, non-small cell lung cancer; RTKs, receptor tyrosine kinases; SCs, stem cells; SCID, severe combined immune-deficient; SF, scatter factor; TKIs, tyrosine kinase inhibitors

Key words: MET receptor, c-met, cancer stem cells, targeted therapy, therapy resistance

\section{Contents}

1. Introduction

2. MET receptor in cancer

3. MET receptor as a prognostic marker

4. Resistance to MET inhibitors

5. MET inhibition overcomes drug resistance

6. MET receptor and stem cells

7. MET receptor and cancer stem cells

8. MET receptor and stem cell markers

9. MET as a CSC factor responsible for therapy resistance 10. Conclusions

\section{Introduction}

The major problem in the fight against cancer is metastatic disease and growing resistance to available therapies. Therefore, it is important to understand the mechanisms responsible for the emergence and development of tumors to establish novel molecular-based strategies to enable a more successful destruction of aggressive tumor disease.

One of the well-known factors connected with tumor growth and metastasis is the MET receptor (1). The MET tyrosine kinase receptor together with its ligand, hepatocyte growth factor (HGF) also known as scatter factor (SF), was identified to play a key role during embriogenesis (2-5). At the early stages of development, HGF and MET, are expressed in endoderm and mesoderm and act in an autocrine manner (2). Later, during organogenesis, MET is expressed in epithelial cells of many organs (liver, kidney, lung and skin), whereas HGF in mesenchymal cells (2). Moreover, MET is expressed in some myoblasts and neuronal precursors, and contributes to the development of muscular and nervous structures $(2,5)$. Crucial role of MET during embryogenesis was confirmed in experiments with knockout mice that died in utero at E15 (4). $\mathrm{HGF} / \mathrm{MET}$ axis is also important in the process of skin, liver and kidney regeneration $(6,7)$.

Ligand-induced MET activation leads to phosphorylation of tyrosine residues (Tyr1230, Tyr1234 and Tyr1235) in the kinase domain of the receptor and allows binding of effector proteins, such as Gab1, Grb2, Shc, PI3K, Src, STAT3 or 
PLC $\gamma$ (8). It activates mainly the RAS-MAPK and PI3K-AKT pathways leading to pleiotropic biological effects on various target cells including the induction of cell proliferation, morphogenetic transformation, cell motility and invasiveness under both normal and pathological conditions (9-11). The last findings also indicate that MET is able to act through c-Abl and $\mathrm{p}-38$-MAPK to induce $\mathrm{p} 53$ phosphorylation and promotes cell survival (12).

The MET receptor is considered a good candidate for targeted therapies (13). However, although MET seems to be a very good target in development of new strategies, both in vitro and in vivo studies have shown that prolonged usage of tyrosine kinase inhibitors results in resistance to treatment and MET has been proposed as a new factor responsible for therapy resistance $(14,15)$. Resistance to treatment is the major limitation and problem of contemporary oncology. This phenomenon may be partially related to the presence of cancer stem cells (CSCs).

The isolation and characterization of CSCs was begun by Lapidot and colleagues (16) who showed that a small population of human acute myeloid leukemic (AML) cells, were capable of initiating human AML after transplantation into severe combined immune-deficient (SCID) mice (16). CSCs as defined by the American Association for Cancer Research (AACR) workshop on CSCs, are a subpopulation of cells in the tumor that have self-renewal capacity and can give rise to heterogeneous cancer cells that comprise the tumor (17). CSCs are defined as cancer-initiating cells (CICs) as well, because of their property of retaining long-term self-renewal ability in vitro, and driving clonal expansion in xenotransplantation assays $(18,19)$. CSCs are inherently resistant to radiochemotherapy owing to efficient DNA repair and self-sustained protection from apoptosis $(18,20,21)$. Growing evidence shows that CSCs are responsible for resistance to conventional therapies, and thus, are the most likely cause of tumor recurrence (22). It has been postulated that stemness features of CSCs allow them to escape conventional antitumor therapy and maintain minimal residual disease, resulting in tumor relapse (23). Recently, it has been shown, in samples from patient tumors, that CSC marker expression is associated with a poorer clinical results and may have prognostic value (24-26). However, identifying markers, that could better characterize and isolate a population of CSCs for some tumors, remains challenging and recently, several potential candidates have been proposed.

The MET receptor has been postulated as an essential factor responsible for the functional cancer stem cell phenotype in some tumors and as a CSC factor is believed to be responsible for therapy resistance. The present review provides examples that MET may be a potential cancer stem cell factor responsible for drug resistance and tumor relapse.

\section{MET receptor in cancer}

In the early 1990s it was shown that mouse and human cell lines with overexpression of HGF and/or MET become tumorigenic and metastatic in nude mice and the level of MET and HGF directly correlates with invasiveness and metastatic process (27). Nowadays, it is well documented that deregulation of MET expression and activity is characteristic for multiple cancer types and is a key event underlying tumor progression and metastasis (1). A large number of studies show that HGF and/or MET are frequently expressed in human carcinomas and in other types of solid tumors and in their metastases (1). MET overexpression has been demonstrated in a variety of tumors, including lung, breast, ovary, cervical, kidney, colon, thyroid, liver, gastric carcinomas, glioma and osteosarcoma (28-41). Activating point mutations of $M E T$ occur in sporadic and inherited human renal carcinomas, hepatocellular carcinomas and several other cancer types $(33,35,42)$.

Moreover, in case of MET and/or its ligand HGF, overexpression or misexpression often correlates with poor prognosis $(1,31,33,37)$. MET was shown to be more frequently amplified in advanced stage of colorectal and gastric cancers suggesting its role in the metastatic process of malignant progression $(33,43,44)$. It was demonstrated for human head and neck cancers that activating mutations of MET are clonally selected during the process of metastasis and its level increased from $2 \%$ in the primary tumors to $50 \%$ in the metastases (45). Interestingly enough, MET expression may vary within the same tumor. As Pennacchietti and colleagues showed (46) both in carcinoma and sarcoma cells hypoxia promotes the expression of met protooncogene and hypoxic areas overexpress the MET receptor leading to activation of invasive growth (46). It was also shown that MET-positive cells within glioblastoma are located close to the nearest blood vessels (47). MET positive cells co-express glioblastoma stem cell markers, CD133 and CD15, compared with MET-negative cells. Moreover, MET expression was efficient in inducing tumor formation regardless of CD133 expression (47). CD133 glycoprotein has been widely used to purify hematopoietic stem and progenitor cells and it was shown to define a subpopulation of brain tumor cells with significantly increased capacity for tumor initiation in xenograft models $(48,49)$. The authors suggest that MET signaling was responsible for glioblastoma stem cell maintenance, migration and resistance to radiation (47).

The group of Comoglio (50) revealed that MET could be genetically selected for the long-term maintenance of the primary transformed phenotype, and some tumors were dependent on sustained MET activity for their growth and survival (51). Moreover, they proposed that MET overexpression in tumors is not only due to transcriptional induction at single-cell level but also expansion of the stem/progenitor subpopulation of cells inherently expressing MET (52). It has been also shown that cells displaying high $M E T$ copy number, overexpression of this receptor and ligand-independent constitutive activation, are addicted to this oncogene and responsive to anti-MET drugs (53-56).

\section{MET receptor as a prognostic marker}

High MET expression pattern is currently associated with increased tumor growth rate and metastasis, poor prognosis and resistance to radiotherapy (57-59). MET overexpression has been postulated as a prognostic factor in lung $(60,61)$, breast (62), head and neck (63), gastric (64), ovarian (65) and clear cell renal cell carcinoma (66). MET overexpression is also associated with poor prognosis and tumor invasiveness in glioblastoma patients $(67,68)$. It has been demonstrated that enhanced level of MET in primary colorectal cancer may 
predict tumor invasion and metastatic process (69). High MET protein level and its activation, resulting from MET amplification, have been reported as associated with a poor prognosis in colorectal and gastric cancers $(33,44,64)$. It was also shown that MET overexpression was significantly associated with worse 3- and 5-year overall survival, progression-free survival and distant metastases in cervical cancer patients (70). Similar results were obtained after a follow-up of 50 months for multiple myeloma patients, where high MET mRNA expression characterized a worse progression-free and overall survival (71). Moreover, co-expression of the MET receptor together with CD47 was proposed as a novel prognostic factor for survival of patients suffering from luminal breast cancer (72). Another study proposed the MET receptor as independent predictor of decreased 5-year survival of patients with invasive ductal breast carcinoma (62). Similar results were obtained by the Edakuni group (73) and showed correlation between co-expression of HGF and MET in breast cancer, histologic grade and reduced patient survival (73). All these examples highlight MET as a prognostic factor whose presence and activity is important for the overall survival and development of metastatic disease in tumor patients.

\section{Resistance to MET inhibitors}

The HGF-MET pathway has been proven to be an attractive drug target for antitumor therapies. Several monoclonal antibodies or small molecules targeting HGF or MET have been discovered and used in monotherapy, in combination with other targeted therapy or with chemotherapy (13). Despite encouraging results involving the use of MET inhibitors in the laboratory and in clinical trials, as well as in studies with other RTK inhibitors, it has been suggested that resistance will develop even in the subset of cancers that initially derive clinical benefits $(14,15)$. Several possible mechanisms of resistance to MET inhibitors such as, MET point mutations, amplification or MET gene overexpression, activation of MET parallel pathways or amplification of the KRAS gene, have been described (74-76). Cepero and colleagues (74) established cell lines resistant to long-term treatment with MET inhibitors and showed that prolonged exposure to increasing doses of c-MET inhibitors leads to amplification, overexpression and activation of wild-type MET and KRAS in gastric cell lines. Furthermore, they observed strong activation of the mitogenactivated protein kinase (MAPK) pathway (74).

Another mechanism of resistance showed that cells developed resistance by acquired mutation in the MET activation loop or activated epidermal growth factor receptor pathway due to increased expression of transforming growth factor $\alpha$ (75). Two other studies showed that overexpression of HER family members in gastric carcinoma cells and non-small cell lung cancer cells are responsible for acquired resistance to MET kinase inhibitors $(76,77)$. The authors concluded that cells carrying high MET copy number will undergo an oncogenic switch that will create an ERBB tyrosine kinase dependency $(76,77)$.

A recent study revealed the acquisition of secondary resistance to MET monoclonal antibodies. In a very elegant study of Martin and coworkers (78), MET-addicted lung cancer cells continuously treated with MET monoclonal antibody became resistant to treatment, as a result of an increase of $M E T$ gene copy number and MET overexpression. However, MET antibody resistant cells were sensitive to MET-specific small tyrosine kinase inhibitors (TKIs) and acquired drugdependence. Moreover, cells resistant to MET TKIs can still be sensitive to treatment with the antibody. The authors suggest that a discontinuous, combined treatment by antibodies and chemical kinase inhibitors may increase the clinical response and bypass resistance to anti-MET targeted therapies through synergistic effect on tumor cells (78). The results demonstrate that despite the acquired resistance to one type of inhibitors, it is possible to use another type and achieve good therapeutic effects. Furthermore, these results show the importance of MET as a therapeutic target.

\section{MET inhibition overcomes drug resistance}

Both in vitro and in vivo studies have shown that prolonged treatment with tyrosine kinases inhibitors (TKIs) results in resistance to treatment and MET receptor has been proposed as a new factor responsible for resistance to targeted therapies including epidermal growth factor receptor (EGFR), vascular endothelial growth factor receptor (VEGFR), human epidermal receptor 2 (HER-2) and B-raf (BRAF) inhibitors (14,15). This phenomenon was demonstrated for the first time in lung cancers driven by mutations in the EGF receptor (79). In the study, $22 \%$ of patients who developed resistance to gefinitib, selective inhibitor of EGFR kinase, demonstrated amplification of the $M E T$ proto-oncogene. The amplification of MET driven ERBB3 (Erb-B2 receptor tyrosine kinase 3) dependent activation of PI3K, a pathway specific to the EGFR/ERBB family receptors, suggests that MET amplification may promote drug resistance in other ERBB-driven cancers (79). It is worth noting, that inhibition of MET signaling restored sensitivity to gefitinib $(79,80)$. Another study reported that MET, as an RTK frequently coexpressed with Her2, in Her2 positive breast cancer, contributes to trastuzumab resistance of Her2-overexpressing breast cancer cells through sustained AKT activation (81).

HGF-MET axis was also shown to be involved in resistance to anti-VEGR therapy. In tumors resistant to inhibitor of VEGF pathway, sunitinib, after treatment with highly selective MET inhibitor, PF-04217903, together with sunitinib, tumor growth was inhibited (82). The study on renal cell carcinoma model demonstrated that the MET receptor is involved in sunitinib acquired resistance (83). Combined treatment with the VEGF and MET inhibitors induced prolonged survival and inhibited tumor growth in mice giving hope for potential therapeutic use in the clinical treatment (83).

In light of these data MET seems to be a very good target for tumors resistant to tyrosine kinase targeted therapies. However, the activity and function of the receptor depend on the cell type and heterogeneity of tumors. Recent studies connect the presence of the MET receptor with cancer stem cell phenotype.

\section{MET receptor and stem cells}

It has been demonstrated that the MET receptor is expressed in stem/progenitor cells in various types of adult normal tissues and maintains stem cell properties. The MET receptor 
was considered as a putative pancreatic stem/progenitor cell marker in adult mouse pancreas $(84,85)$. In the developing liver, cells expressing MET can form stem cell colonies in vitro and migrate and differentiate into liver parenchymal cells and cholangiocytes when they were transplanted into the spleen or liver of mice subjected to liver injury (86). The essential role of the HGF/MET axis in hepatocyte-mediated liver regeneration, was shown by Ishikawa and colleagues with the use of MET knockout mice (87). In the liver, the MET receptor supported survival, proliferation, sphere formation and differentiation properties of oval cells (87). Another study showed that MET, in cardiac stem cells and early committed cells, is responsible for proliferation, survival, migration and regeneration of the infracted myocardium and improvement of ventricular function (88).

The study by Chmielowiec et al (89) underlined a fundamental role of MET during regenerative process in the adult skin. The authors demonstrated that MET signaling not only controls growth and migration of keratinocytes during embryogenesis but is also essential for the generation of the hyperproliferative epithelium in skin wounds (89). It was also demonstrated that MET signaling is a key mechanism in maintaining stem cell niche in brain important for neural stem cell growth and self-renewal (90).

\section{MET receptor and cancer stem cells}

Recently, the MET receptor has been postulated as an essential factor responsible for the functional CSCs phenotype in some tumors. It was reported that MET expression was associated with glioblastoma stem cells (GSCs) identified by prospective isolation from fresh tumors (47) or with neurospheres endowed with specific genetic/molecular features (91). Furthermore, MET was considered to play a central role in maintaining CSC populations in human glioblastoma multiforme (GBM), suggesting a link between MET signaling and CSCs $(91,92)$. Other studies, on GBM cell subpopulations, showed that only cells expressing high level of MET retained clonogenic, tumorigenic and radioresistant properties, features of CSCs $(47,91)$. The authors demonstrated pivotal role of MET in supporting the pool of GBM SCs (47). They used freshly isolated patientderived GBM cells and provided evidence suggesting that MET plays critical role in SC maintenance, migration and resistance to radiation (47). Subpopulation with high MET level displayed enhanced kinetics growth and was highly tumorigenic in vivo as well $(47,91)$. Moreover, only small population of GBM cells has been shown to be positive for the MET receptor and to contain amplification of MET, independent of other RTKs $(93,94)$. The study by Li et al (95) involved MET as a novel, functional, stem cell marker for pancreatic adenocarcinoma. The authors identified the population with a high expression of MET and suggested that the receptor regulates SCs proliferation, cell renewal and has the ability to form tumors in NOD/SCID mice (95). This study also showed that the use of the MET inhibitor or small hairpin RNAs in pancreatic adenocarcinoma significantly inhibited tumor sphere formation and self-renewal capacity (95). In pancreatic tumors established in NOD SCID mice, MET inhibition decreased tumor growth, reduced the population of CSCs and prevented the development of metastases (95). The study of Sun and Wang (96) on human head and neck squamous
Table I. MET expression and cancer stem cell phenotype.

\begin{tabular}{lc}
\hline Tumor type & Refs. \\
\hline Breast cancer & $(98)$ \\
Colon cancer & $(115)$ \\
Glioblastoma & $(47,91,92,103)$ \\
Head and neck & $(96)$ \\
Pancreatic adenocarcinoma & $(95)$ \\
Prostate cancer & $(97)$
\end{tabular}

Association of MET expression with the stem/progenitor status.

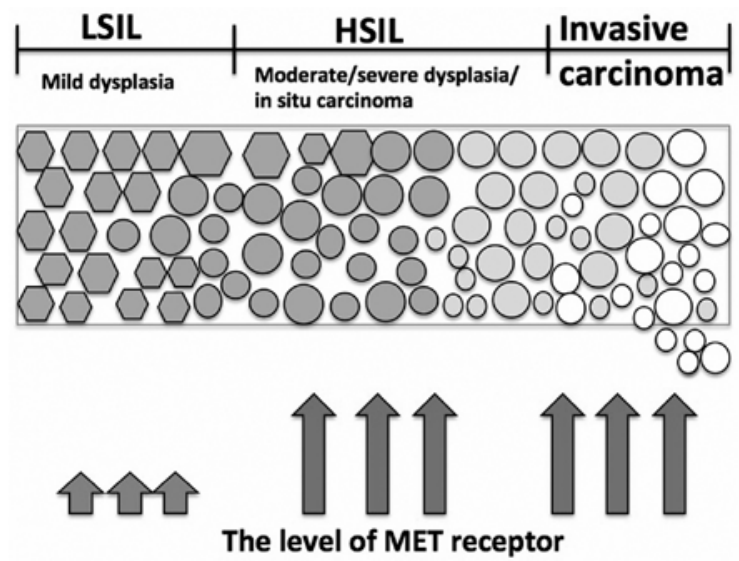

Figure 1. Immunohistochemical staining showed marked increase in the level of MET receptor in samples from cervical cancer patients (101).

cell carcinoma (HNSCC) demonstrated that MET expressing cells have the capacity for self-renewal (96). Furthermore, the MET receptor was responsible for tumor formation and metastatic process in NOD/SCID mice and cisplatin resistance (96). It was also shown that the HGF/MET axis regulates stem- like phenotype in human prostate cancer (97). The study of Gastaldi and coworkers (98) emphasized the role of MET in breast tumorigenesis. The authors showed that MET acts as a critical regulator of luminal cell proliferation and differentiation in the context of murine mammary morphogenesis (98). Moreover, the authors presented that MET is preferentially expressed in luminal progenitors and its activation stimulates clonogenic activity in vitro, confers repopulating potential in vivo and promotes aberrant branching morphogenesis (98). Table I summarizes the data with reference to MET expression correlated with cancer stem cell phenotype.

Our study on rhabdomyosarcoma showed that silencing of the MET receptor stimulates tumor cell differentiation and activation of MET signaling may be the cause of its development and progression $(99,100)$. We have also demonstrated that cervical cancer cells depend on sustained MET activity for their growth and survival and downregulation of MET decreased tumor growth and forced tumor differentiation in vivo (101). Our observation on cervical cancer patient samples revealed that low level of MET accompanied low-grade squamous intraepithelial lesion, whereas increased heavily in high-grade squamous intraepithelial lesion and invasive carcinoma (101) (Fig. 1). 
Table II. MET expression and cancer stem cell factors.

\begin{tabular}{lllr}
\hline Stem cell marker & \multicolumn{1}{c}{ Function } & \multicolumn{1}{c}{ Tumor type } \\
\hline Sox2 & Transcription factor & Glioblastoma pancreatic cancer & Glioblastoma \\
Klf4 & Transcription factor & Glioblastoma & $(92)$ \\
c-Myc & Transcription factor & Glioblastoma \\
Oct4 & Transcription factor & Glioblastoma \\
Nanog & Transcription factor & Prostate cancer & $(92,103)$ \\
CD49b & $\alpha_{2}$ integrin & Prostate cancer & $(92,103)$ \\
CD49f & $\alpha_{6}$ integrin subunit & Pancreatic cancer \\
CD133 & Stem cell biomarker & Rhabdomyosarcoma, cervical carcinoma \\
CXCR4 & Chemokine receptor & $(97)$ \\
\hline
\end{tabular}

Correlation of MET receptor and stem/progenitor factors.

\section{MET receptor and stem cell markers}

The MET receptor not only supports stem-like phenotype of cancer cells but also affects the expression and activity of stem cell markers. It has been shown that MET signaling can regulate glioma subpopulations and expand the pool of stem-like cells. The study of $\mathrm{Li}$ and colleagues (92) revealed that MET positively correlates with stem cell marker expression and the neoplastic stem cell phenotype in glioblastoma neurospheres, as well as in clinical glioblastoma specimens. MET expression and activation influences the expression of reprogramming transcription factors known to support embryonic stem cells, Sox2, Klf4, c-Myc, Oct4 and Nanog, known to induce stem-like properties in differentiated cells $(92,102)$. Moreover, MET enhances stem cell characteristics of neurosphere formation and neurosphere cell self-renewal (92). The MET receptor supports the GBM SC phenotype by involving an endogenous dynamic mechanism analogous to cellular reprogramming (92). It was shown that MET-positive cells expressed high levels of stemness transcriptional regulators, Oct4, Nanog and Klf4, when compared to MET-negative cells and the activation of MET signaling increases the expression of the Oct4, Nanog and Klf4 (103). The expression returned to basal levels in response to MET inhibition (103). It was also shown that MET induces a stem-like phenotype in prostate cancer and is expressed together with stem-like markers CD49b and CD49f and (97). Another study reported that cabozantinib, a novel inhibitor of MET, downregulated CSC markers, SOX2 and CD133, induced apoptosis and increased efficacy of gemcitabine, currently used in standard therapy for advanced pancreatic cancer (104).

In our study, we have reported that blocking of the MET receptor could influence expression and function of the chemokine CXCR4 receptor in rhabdomyosarcoma and cervical carcinoma cells $(99,101)$. Cells with decreased MET expression had impaired intracellular signaling and chemotaxis toward SDF-1 gradient, a ligand of the CXCR4 receptor, which was in accordance with decreased expression of CXCR4 $(99,101)$. CXCR4 overexpression and hyperactivation was shown for the first time to correlate with the metastatic ability of breast cancer cells (105). Since that time, the SDF-1-CXCR4 axis has been shown to be involved in the regulation of metastasis to organs that highly express SDF-1 (e.g., lymph nodes, lungs, liver and bones) (106). It was postulated that cancer stem cells and trafficking of normal stem cells involve similar mechanisms regulated partially by CXCR4 (107).

Table II summarizes the study of the correlation between the MET receptor and cancer stem cell markers.

\section{MET as a CSC factor responsible for therapy resistance}

Growing evidence shows that CSCs are responsible for resistance to conventional therapies, and thus, are the most likely cause of tumor recurrence (22). It has been postulated that stemness features of CSCs would allow them to escape conventional antitumor therapy and maintain minimal residual disease, leading to tumor relapse (23). It has been shown for breast cancer (108) and glioma (21) that CSCs survived after radiation, repaired their damaged DNA more efficiently than their non-CSC counterparts and began the process of selfrenewal $(21,108)$. Recently, it has been shown, in samples from patient tumors, that CSC marker expression is associated with a poor clinical outcome and may have prognostic value (24-26,109).

The study of Bardelli and colleagues (110) with the use of human colorectal cancer metastases xenografted in mice, demonstrated that amplification of the MET oncogene is a mechanism of both primary and secondary resistance to antiEGFR therapies. In the study by Jun et al (103) the authors used a mouse model of GBM and demonstrated that treatment of EGFR-positive GBM with gefitinib, a TKI, results in the induction of MET expression in a subset of cells that have GSC characteristics. MET signaling was a requisite for initiation and maintenance of the GSC features. The results emphasized the capacity for MET to support the GSC phenotype that involves an endogenous dynamic mechanism analogous to cellular reprogramming (103). It was also presented that MET amplification mediates in developing of EGFR tyrosine kinase inhibitors resistance in EGFR-mutant lung cancer cells $(111,112)$. The authors showed that small population of cells carrying $M E T$ amplification may pre-exist in EGFR-mutated lung cancers. These cells, not driven by EGFR mutations, can be positively selected by therapy with EGFR inhibitors and sustain resistance to EGFR inhibitors (111). It was demonstrated that the 


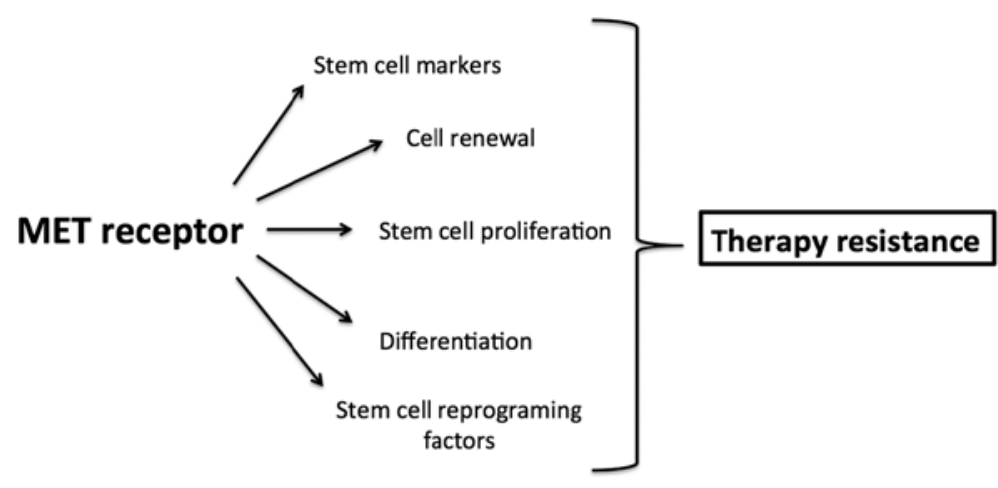

Figure 2. MET receptor as a biological factor responsible for cancer stem cell properties and therapy resistance.

response to specific inhibitors was efficiently counteracted by a variety of growth factors with prominent role of the MET receptor ligand HGF (111,112). BRAF-mutant melanomas or ERBB2-driven carcinomas have been also rescued from drug sensitivity by exposing them to HGF $(113,114)$. Recent study of Luraghi and coworkers (115), showed that effects of EGFR inhibition in sensitive colorectal cancer initiating cells (CCIC) could be counteracted by HGF supporting in vitro CCIC proliferation and resistance to EGFR inhibition. It was also shown, for colon cancer, that HGF, secreted by tumor microenvironment, activates $\beta$-catenin-dependent transcription and thereby influences CSC clonogenicity and restores the CSC phenotype in more differentiated tumor cells both in vitro and in vivo $(116,117)$.

All the observations are clinically appealing because combined treatment with an EGFR and MET inhibitor, specifically in patients with evidence of MET amplification at baseline, may lead to extended progression and better outcome.

A study showed that MET amplification together with EMT, and stem cell-like features are observed in non-small cell lung cancer cells with acquired resistance to Afatinib, an EGFR-TKI (118). It was also demonstrated that resistance of non-small lung cancer patients to EGFR inhibitors is due to EGFR T790M mutation and MET amplification (119). Moreover, the patients acquired resistance to the MET receptor inhibitors used as a therapeutic approach in clinical trials. The mechanism of the resistance involved ABCB1 overexpression, which was associated with CSC properties and EMT (119).

Taken together, MET involved in enhancing and maintaining cancer stem cell properties may be responsible for resistance to antitumor therapy (Fig. 2).

\section{Conclusions}

Targeted therapies with compounds inhibiting a specific target molecule opened a new direction in the treatment of cancer. The development of targeted therapies requires the identification of good targets that are known to play a key role in tumor cell growth and survival and are more effective and less toxic than previous standards of care involving cytotoxic therapies (120). Targeted therapy relies on the concept of 'oncogene addiction' that reveals a possible 'Achilles' heel' of cancer cells, wherein they depend on a single oncogenic pathway for sustained proliferation and/or survival $(121,122)$. This means that the inhibition of a single pathway, gene or protein to which they are addicted results in the inhibition of their growth or even their death (121). Unfortunately, targeted therapeutics in cancer has not yet met the high expectations of patients and physicians because some patients relapsed following treatment with specific inhibitors as a result of acquired resistance mechanisms $(120,123)$. CSCs have been shown to be largely responsible for chemoresistant phenotypes in various tumors, thus, the development of new, targeted, effective therapies has become focused on identifying factors that drive and sustain CSCs. The CSC hypothesis predicts that only therapies that efficiently eliminate population of CSCs are able to induce long-term response and stop tumor recurrence. The activation of the MET receptor axis has been directly implicated in acquiring chemoresistance, maintaining clonogenicity and ability to self-renew in various tumor cell populations. In the light of our knowledge MET seems to have two faces: acts as a promising factor for developing personalized cancer therapy and as a factor responsible for cancer stem cell properties and therapy resistance.

\section{Acknowledgements}

The present study was supported by a grant from the National Science Centre (no. 2013/09/D/NZ5/00249) to K.M. The Faculty of Biochemistry, Biophysics and Biotechnology of the Jagiellonian University is a beneficiary of the structural funds from the European Union and the Polish Ministry of Science and Higher Education (grants nos. POIG.02.01.00-12-064/08 and 02.02.00-00-014/08) and is a partner of the Leading National Research Center (KNOW) supported by the Ministry of Science and Higher Education. I am very grateful to Mikolaj Przywara for language editing, proofreading and suggestions.

\section{References}

1. Birchmeier C, Birchmeier W, Gherardi E and Vande Woude GF: Met, metastasis, motility and more. Nat Rev Mol Cell Biol 4: 915-925, 2003.

2. Andermarcher E, Surani MA and Gherardi E: Co-expression of the HGF/SF and c-met genes during early mouse embryogenesis precedes reciprocal expression in adjacent tissues during organogenesis. Dev Genet 18: 254-266, 1996. 
3. Schmidt C, Bladt F, Goedecke S, Brinkmann V, Zschiesche W, Sharpe M, Gherardi E and Birchmeier C: Scatter factor/hepatocyte growth factor is essential for liver development. Nature 373 699-702, 1995

4. Uehara Y, Minowa O, Mori C, Shiota K, Kuno J, Noda T and Kitamura N: Placental defect and embryonic lethality in mice lacking hepatocyte growth factor/scatter factor. Nature 373: 702-705, 1995

5. Maina F, Hilton MC, Ponzetto C, Davies AM and Klein R: Met receptor signaling is required for sensory nerve development and HGF promotes axonal growth and survival of sensory neurons. Genes Dev 11: 3341-3350, 1997.

6. Borowiak M, Garratt AN, Wüstefeld T, Strehle M, Trautwein C and Birchmeier C: Met provides essential signals for liver regeneration. Proc Natl Acad Sci USA 101: 10608-10613, 2004

7. Huh CG, Factor VM, Sánchez A, Uchida K, Conner EA and Thorgeirsson SS: Hepatocyte growth factor/c-met signaling pathway is required for efficient liver regeneration and repair. Proc Natl Acad Sci USA 101: 4477-4482, 2004.

8. Furlan A, Kherrouche Z, Montagne R, Copin MC and Tulasne D: Thirty years of research on met receptor to move a biomarker from bench to bedside. Cancer Res 74: 6737-6744, 2014.

9. Kermorgant S, Aparicio T, Dessirier V, Lewin MJ and Lehy T: Hepatocyte growth factor induces colonic cancer cell invasiveness via enhanced motility and protease overproduction. Evidence for PI3 kinase and PKC involvement. Carcinogenesis 22: 1035-1042, 2001.

10. Weidner KM, Sachs M and Birchmeier W: The Met receptor tyrosine kinase transduces motility, proliferation, and morphogenic signals of scatter factor/hepatocyte grow th factor in epithelial cells. J Cell Biol 121: 145-154, 1993.

11. Trusolino L, Bertotti A and Comoglio PM: MET signalling: Principles and functions in development, organ regeneration and cancer. Nat Rev Mol Cell Biol 11: 834-848, 2010.

12. Furlan A, Stagni V, Hussain A, Richelme S, Conti F, Prodosmo A, Destro A, Roncalli M, Barilà D and Maina F: Abl interconnects oncogenic Met and p53 core pathways in cancer cells. Cell Death Differ 18: 1608-1616, 2011.

13. Vigna E and Comoglio PM: Targeting the oncogenic Met receptor by antibodies and gene therapy. Oncogene 34: 1883-1889, 2015.

14. Engelman JA and Settleman J: Acquired resistance to tyrosine kinase inhibitors during cancer therapy. Curr Opin Genet Dev 18: 73-79, 2008

15. Sierra JR, Cepero V and Giordano S: Molecular mechanisms of acquired resistance to tyrosine kinase targeted therapy. Mol Cancer 9: 75, 2010.

16. Lapidot T, Sirard C, Vormoor J, Murdoch B, Hoang T, Caceres-Cortes J, Minden M, Paterson B, Caligiuri MA and Dick JE: A cell initiating human acute myeloid leukaemia after transplantation into SCID mice. Nature 367: 645-648, 1994.

17. Clarke MF, Dick JE, Dirks PB, Eaves CJ, Jamieson $\mathrm{CH}$ Jones DL, Visvader J, Weissman IL and Wahl GM: Cancer stem cells - perspectives on current status and future directions: AACR Workshop on cancer stem cells. Cancer Res 66: 9339-9344, 2006

18. O'Brien CA, Pollett A, Gallinger S and Dick JE: A human colon cancer cell capable of initiating tumour growth in immunodeficient mice. Nature 445: 106-110, 2007.

19. Ricci-Vitiani L, Lombardi DG, Pilozzi E, Biffoni M, Todaro M Peschle $C$ and De Maria R: Identification and expansion of human colon-cancer-initiating cells. Nature 445: 111-115, 2007.

20. Chen J, Li Y, Yu TS, McKay RM, Burns DK, Kernie SG and Parada LF: A restricted cell population propagates glioblastoma growth after chemotherapy. Nature 488: 522-526, 2012.

21. Bao S, Wu Q, McLendon RE, Hao Y, Shi Q, Hjelmeland AB, Dewhirst MW, Bigner DD and Rich JN: Glioma stem cells promote radioresistance by preferential activation of the DNA damage response. Nature 444: 756-760, 2006.

22. Kreso A and Dick JE: Evolution of the cancer stem cell model. Cell Stem Cell 14: 275-291, 2014.

23. Ghiaur G, Gerber J and Jones RJ: Concise review: Cancer stem cells and minimal residual disease. Stem Cells 30: 89-93, 2012.

24. Maeda S, Shinchi H, Kurahara H, Mataki Y, Maemura K, Sato M, Natsugoe S, Aikou T and Takao S: CD133 expression is correlated with lymph node metastasis and vascular endothelial growth factor-C expression in pancreatic cancer. Br J Cancer 98: 1389-1397, 2008

25. Vogler T, Kriegl L, Horst D, Engel J, Sagebiel S, Schäffauer AJ, Kirchner $\mathrm{T}$ and Jung A: The expression pattern of aldehyde dehydrogenase 1 (ALDH1) is an independent prognostic marker for low survival in colorectal tumors. Exp Mol Pathol 92: 111-117, 2012 .
26. Zeppernick F, Ahmadi R, Campos B, Dictus C, Helmke BM, Becker N, Lichter P, Unterberg A, Radlwimmer B and HeroldMende CC: Stem cell marker CD133 affects clinical outcome in glioma patients. Clin Cancer Res 14: 123-129, 2008.

27. Rong S, Segal S, Anver M, Resau JH and Vande Woude GF: Invasiveness and metastasis of NIH 3T3 cells induced by Met-hepatocyte growth factor/scatter factor autocrine stimulation. Proc Natl Acad Sci USA 91: 4731-4735, 1994.

28. Tokunou M, Niki T, Eguchi K, Iba S, Tsuda H, Yamada T, Matsuno Y, Kondo H, Saitoh Y, Imamura H, et al: c-MET expression in myofibroblasts: Role in autocrine activation and prognostic significance in lung adenocarcinoma. Am J Pathol 158: 1451-1463, 2001.

29. Tsao MS, Liu N, Chen JR, Pappas J, Ho J, To C, Viallet J, Park M and Zhu H: Differential expression of Met/hepatocyte growth factor receptor in subtypes of non-small cell lung cancers. Lung Cancer 20: 1-16, 1998

30. Olivero M, Rizzo M, Madeddu R, Casadio C, Pennacchietti S, Nicotra MR, Prat M, Maggi G, Arena N, Natali PG, et al: Overexpression and activation of hepatocyte growth factor/ scatter factor in human non-small-cell lung carcinomas. Br J Cancer 74: 1862-1868, 1996.

31. LengyelE,PrechtelD, Resau JH, Gauger K, Welk A,Lindemann K, Salanti G, Richter T, Knudsen B, Vande Woude GF, et al: C-Met overexpression in node-positive breast cancer identifies patients with poor clinical outcome independent of Her2/neu. Int J Cancer 113: 678-682, 2005.

32. Di Renzo MF, Olivero M, Katsaros D, Crepaldi T, Gaglia P, Zola P, Sismondi P and Comoglio PM: Overexpression of the Met/HGF receptor in ovarian cancer. Int J Cancer 58: 658-662, 1994.

33. Di Renzo MF, Olivero M, Giacomini A, Porte H, Chastre E, Mirossay L, Nordlinger B, Bretti S, Bottardi S, Giordano S, et al: Overexpression and amplification of the met/HGF receptor gene during the progression of colorectal cancer. Clin Cancer Res 1: 147-154, 1995.

34. Natali PG, Prat M, Nicotra MR, Bigotti A, Olivero M, Comoglio PM and Di Renzo MF: Overexpression of the met/ HGF receptor in renal cell carcinomas. Int J Cancer 69: 212-217, 1996.

35. Schmidt L, Duh FM, Chen F, Kishida T, Glenn G, Choyke P, Scherer SW, Zhuang Z, Lubensky I, Dean M, et al: Germline and somatic mutations in the tyrosine kinase domain of the MET proto-oncogene in papillary renal carcinomas. Nat Genet 16: 68-73, 1997.

36. Knowles LM, Stabile LP, Egloff AM, Rothstein ME, Thomas SM, Gubish CT, Lerner EC, Seethala RR, Suzuki S, Quesnelle KM, et al: HGF and c-Met participate in paracrine tumorigenic pathways in head and neck squamous cell cancer. Clin Cancer Res 15: 3740-3750, 2009.

37. Ramirez R, Hsu D, Patel A, Fenton C, Dinauer C, Tuttle RM and Francis GL: Over-expression of hepatocyte growth factor/scatter factor (HGF/SF) and the HGF/SF receptor (cMET) are associated with a high risk of metastasis and recurrence for children and young adults with papillary thyroid carcinoma. Clin Endocrinol (Oxf) 53: 635-644, 2000

38. Soman NR, Correa P, Ruiz BA and Wogan GN: The TPR-MET oncogenic rearrangement is present and expressed in human gastric carcinoma and precursor lesions. Proc Natl Acad Sci USA 88: 4892-4896, 1991.

39. Koochekpour S, Jeffers M, Rulong S, Taylor G, Klineberg E, Hudson EA, Resau JH and Vande Woude GF: Met and hepatocyte growth factor/scatter factor expression in human gliomas. Cancer Res 57: 5391-5398, 1997.

40. Ferracini R, Di Renzo MF, Scotlandi K, Baldini N, Olivero M, Lollini P, Cremona O, Campanacci M and Comoglio PM: The Met/HGF receptor is over-expressed in human osteosarcomas and is activated by either a paracrine or an autocrine circuit. Oncogene 12: 1697-1705, 1996.

41. Di Renzo MF, Poulsom R, Olivero M, Comoglio PM and Lemoine NR: Expression of the Met/hepatocyte growth factor receptor in human pancreatic cancer. Cancer Res 55: 1129-1138, 1995.

42. Ma PC, Tretiakova MS, MacKinnon AC, Ramnath N, Johnson C, Dietrich S, Seiwert T, Christensen JG, Jagadeeswaran R, Krausz T, et al: Expression and mutational analysis of MET in human solid cancers. Genes Chromosomes Cancer 47: 1025-1037, 2008. 
43. Zeng ZS, Weiser MR, Kuntz E, Chen CT, Khan SA, Forslund A, Nash GM, Gimbel M, Yamaguchi Y, Culliford AT IV, et al: c-Met gene amplification is associated with advanced stage colorectal cancer and liver metastases. Cancer Lett 265: 258-269, 2008.

44. Tsugawa K, Yonemura Y, Hirono Y, Fushida S, Kaji M, Miwa K, Miyazaki I and Yamamoto H: Amplification of the c-met, c-erbB-2 and epidermal growth factor receptor gene in human gastric cancers: Correlation to clinical features. Oncology 55: 475-481, 1998.

45. Di Renzo MF, Olivero M, Martone T, Maffe A, Maggiora P, Stefani AD, Valente G, Giordano S, Cortesina G and Comoglio PM: Somatic mutations of the MET oncogene are selected during metastatic spread of human HNSC carcinomas. Oncogene 19: 1547-1555, 2000.

46. Pennacchietti S, Michieli P, Galluzzo M, Mazzone M, Giordano S and Comoglio PM: Hypoxia promotes invasive growth by transcriptional activation of the met protooncogene. Cancer Cell 3 347-361, 2003.

47. Joo KM, Jin J, Kim E, Ho Kim K, Kim Y, Gu Kang B, Kang YJ, Lathia JD, Cheong KH, Song PH, et al: MET signaling regulates glioblastoma stem cells. Cancer Res 72: 3828-3838, 2012.

48. Singh SK, Clarke ID, Terasaki M, Bonn VE, Hawkins C, Squire J and Dirks PB: Identification of a cancer stem cell in human brain tumors. Cancer Res 63: 5821-5828, 2003.

49. Bidlingmaier S, Zhu X and Liu B: The utility and limitations of glycosylated human CD133 epitopes in defining cancer stem cells. J Mol Med (Berl) 86: 1025-1032, 2008.

50. Comoglio PM, Giordano S and Trusolino L: Drug development of MET inhibitors: Targeting oncogene addiction and expedience. Nat Rev Drug Discov 7: 504-516, 2008.

51. Benvenuti S, Lazzari L, Arnesano A, Li Chiavi G, Gentile A and Comoglio PM: Ron kinase transphosphorylation sustains MET oncogene addiction. Cancer Res 71: 1945-1955, 2011.

52. Boccaccio $\mathrm{C}$ and Comoglio PM: The MET oncogene in glioblastoma stem cells: Implications as a diagnostic marker and a therapeutic target. Cancer Res 73: 3193-3199, 2013.

53. Corso S, Migliore C, Ghiso E, De Rosa G, Comoglio PM and Giordano S: Silencing the MET oncogene leads to regression of experimental tumors and metastases. Oncogene 27: 684-693, 2008.

54. Lennerz JK, Kwak EL, Ackerman A, Michael M, Fox SB, Bergethon K, Lauwers GY, Christensen JG, Wilner KD, Haber DA, et al: MET amplification identifies a small and aggressive subgroup of esophagogastric adenocarcinoma with evidence of responsiveness to crizotinib. J Clin Oncol 29: 4803-4810, 2011.

55. Lutterbach B, Zeng Q, Davis LJ, Hatch H, Hang G, Kohl NE, Gibbs JB and Pan BS: Lung cancer cell lines harboring MET gene amplification are dependent on Met for growth and survival. Cancer Res 67: 2081-2088, 2007.

56. Smolen GA, Sordella R, Muir B, Mohapatra G, Barmettler A, Archibald H, Kim WJ, Okimoto RA, Bell DW, Sgroi DC, et al: Amplification of MET may identify a subset of cancers with extreme sensitivity to the selective tyrosine kinase inhibitor PHA-665752. Proc Natl Acad Sci USA 103: 2316-2321, 2006.

57. De Bacco F, Luraghi P, Medico E, Reato G, Girolami F, Perera T, Gabriele P, Comoglio PM and Boccaccio C: Induction of MET by ionizing radiation and its role in radioresistance and invasive growth of cancer. J Natl Cancer Inst 103: 645-661, 2011.

58. Matsui S, Osada S, Tomita H, Komori S, Mori R, Sanada Y, Takahashi T, Yamaguchi K and Yoshida K: Clinical significance of aggressive hepatectomy for colorectal liver metastasis evaluated from the HGF/c-Met pathway. Int J Oncol 37: 289-297, 2010 .

59. Navab R, Liu J, Seiden-Long I, Shih W, Li M, Bandarchi B, Chen Y, Lau D, Zu YF, Cescon D, et al: Co-overexpression of Met and hepatocyte growth factor promotes systemic metastasis in NCI-H460 non-small cell lung carcinoma cells. Neoplasia 11: 1292-1300, 2009.

60. Cai YR, Zhang HQ, Qu Y, Mu J, Zhao D, Zhou LJ, Yan H, Ye JW and Liu Y: Expression of MET and SOX2 genes in non-small cell lung carcinoma with EGFR mutation. Oncol Rep 26: 877-885, 2011.

61. Masuya D, Huang C, Liu D, Nakashima T, Kameyama K, Haba R, Ueno M and Yokomise H: The tumour-stromal interaction between intratumoral c-Met and stromal hepatocyte growth factor associated with tumour growth and prognosis in nonsmall-cell lung cancer patients. Br J Cancer 90: 1555-1562, 2004.
62. Ghoussoub RA, Dillon DA, D'Aquila T, Rimm EB, Fearon ER and Rimm DL: Expression of c-met is a strong independent prognostic factor in breast carcinoma. Cancer 82: 1513-1520, 1998.

63. Qian CN, Guo X, Cao B, Kort EJ, Lee CC, Chen J, Wang LM, Mai WY, Min HQ, Hong MH, et al: Met protein expression level correlates with survival in patients with late-stage nasopharyngeal carcinoma. Cancer Res 62: 589-596, 2002.

64. Nakajima M, Sawada H, Yamada Y, Watanabe A, Tatsumi M, Yamashita J, Matsuda M, Sakaguchi T, Hirao T and Nakano H: The prognostic significance of amplification and overexpression of c-met and c-erb B-2 in human gastric carcinomas. Cancer 85: 1894-1902, 1999

65. Sawada K, Radjabi AR, Shinomiya N, Kistner E, Kenny H, Becker AR, Turkyilmaz MA, Salgia R, Yamada SD, Vande Woude GF, et al: c-Met overexpression is a prognostic factor in ovarian cancer and an effective target for inhibition of peritoneal dissemination and invasion. Cancer Res 67: 1670-1679, 2007.

66. Gibney GT, Aziz SA, Camp RL, Conrad P, Schwartz BE, Chen CR, Kelly WK and Kluger HM: c-Met is a prognostic marker and potential therapeutic target in clear cell renal cell carcinoma. Ann Oncol 24: 343-349, 2013.

67. Nabeshima K, Shimao Y, Sato S, Kataoka H, Moriyama T, Kawano H, Wakisaka S and Koono M: Expression of c-Met correlates with grade of malignancy in human astrocytic tumours: An immunohistochemical study. Histopathology 31: 436-443, 1997

68. Kong DS, Song SY, Kim DH, Joo KM, Yoo JS, Koh JS, Dong SM, Suh YL, Lee JI, Park K, et al: Prognostic significance of c-Met expression in glioblastomas. Cancer 115: 140-148, 2009.

69. Takeuchi H, Bilchik A, Saha S, Turner R, Wiese D, Tanaka M, Kuo C, Wang HJ and Hoon DS: c-MET expression level in primary colon cancer: A predictor of tumor invasion and lymph node metastases. Clin Cancer Res 9: 1480-1488, 2003.

70. Refaat T, Donnelly ED, Sachdev S, Parimi V, El Achy S, Dalal P, Farouk M, Berg N, Helenowski I, Gross JP, et al: c-Met overexpression in cervical cancer, a prognostic factor and a potential molecular therapeutic target. Am J Clin Oncol: Jun 10, 2015 (Epub ahead of print).

71. Rocci A, Gambella M, Aschero S, Baldi I, Trusolino L, Cavallo F, Gay F, Larocca A, Magarotto V, Omedè P, et al: MET dysregulation is a hallmark of aggressive disease in multiple myeloma patients. Br J Haematol 164: 841-850, 2014.

72. Baccelli I, Stenzinger A, Vogel V, Pfitzner BM, Klein C, Wallwiener M, Scharpff M, Saini M, Holland-Letz T, Sinn HP, et al: Co-expression of MET and CD47 is a novel prognosticator for survival of luminal breast cancer patients. Oncotarget 5 : 8147-8160, 2014.

73. Edakuni G, Sasatomi E, Satoh T, Tokunaga O and Miyazaki K: Expression of the hepatocyte growth factor/c-Met pathway is increased at the cancer front in breast carcinoma. Pathol Int 51: 172-178, 2001.

74. Cepero V, Sierra JR, Corso S, Ghiso E, Casorzo L, Perera T, Comoglio PM and Giordano S: MET and KRAS gene amplification mediates acquired resistance to MET tyrosine kinase inhibitors. Cancer Res 70: 7580-7590, 2010.

75. Qi J, McTigue MA, Rogers A, Lifshits E, Christensen JG, Jänne PA and Engelman JA: Multiple mutations and bypass mechanisms can contribute to development of acquired resistance to MET inhibitors. Cancer Res 71: 1081-1091, 2011.

76. Corso S, Ghiso E, Cepero V, Sierra JR, Migliore C, Bertotti A, Trusolino L, Comoglio PM and Giordano S: Activation of HER family members in gastric carcinoma cells mediates resistance to MET inhibition. Mol Cancer 9: 121, 2010.

77. McDermott U, Pusapati RV, Christensen JG, Gray NS and Settleman J: Acquired resistance of non-small cell lung cancer cells to MET kinase inhibition is mediated by a switch to epidermal growth factor receptor dependency. Cancer Res 70: 1625-1634, 2010.

78. Martin V, Corso S, Comoglio PM and Giordano S: Increase of MET gene copy number confers resistance to a monovalent MET antibody and establishes drug dependence. Mol Oncol 8: 1561-1574, 2014

79. Engelman JA, Zejnullahu K, Mitsudomi T, Song Y, Hyland C, Park JO, Lindeman N, Gale CM, Zhao X, Christensen J, et al: MET amplification leads to gefitinib resistance in lung cancer by activating ERBB3 signaling. Science 316: 1039-1043, 2007. 
80. Bean J, Brennan C, Shih JY, Riely G, Viale A, Wang L, Chitale D, Motoi N, Szoke J, Broderick S, et al: MET amplification occurs with or without T790M mutations in EGFR mutant lung tumors with acquired resistance to gefitinib or erlotinib. Proc Natl Acad Sci USA 104: 20932-20937, 2007.

81. Shattuck DL, Miller JK, Carraway KL III and Sweeney C: Met receptor contributes to trastuzumab resistance of Her2overexpressing breast cancer cells. Cancer Res 68: 1471-1477, 2008.

82. Shojaei F, Lee JH, Simmons BH, Wong A, Esparza CO, Plumlee PA, Feng J, Stewart AE, Hu-Lowe DD and Christensen JG: HGF/c-Met acts as an alternative angiogenic pathway in sunitinib-resistant tumors. Cancer Res 70 10090-10100, 2010.

83. Ciamporcero E, Miles KM, Adelaiye R, Ramakrishnan S, Shen L, Ku S, Pizzimenti S, Sennino B, Barrera G and Pili R: Combination strategy targeting VEGF and HGF/c-met in human renal cell carcinoma models. Mol Cancer Ther 14: 101-110, 2015.

84. Teng C, Guo Y, Zhang H, Zhang H, Ding M and Deng H: Identification and characterization of label-retaining cells in mouse pancreas. Differentiation 75: 702-712, 2007.

85. Oshima Y, Suzuki A, Kawashimo K, Ishikawa M, Ohkohchi N and Taniguchi $\mathrm{H}$ : Isolation of mouse pancreatic ductal progenitor cells expressing CD133 and c-Met by flow cytometric cell sorting. Gastroenterology 132: 720-732, 2007.

86. Kamiya A, Gonzalez FJ and Nakauchi H: Identification and differentiation of hepatic stem cells during liver development. Front Biosci 11: 1302-1310, 2006.

87. Ishikawa T, Factor VM, Marquardt JU, Raggi C, Seo D, Kitade M, Conner EA and Thorgeirsson SS: Hepatocyte growth factor/c-met signaling is required for stem-cell-mediated liver regeneration in mice. Hepatology 55: 1215-1226, 2012.

88. Urbanek K, Rota M, Cascapera S, Bearzi C, Nascimbene A, De Angelis A, Hosoda T, Chimenti S, Baker M, Limana F, et al: Cardiac stem cells possess growth factor-receptor systems that after activation regenerate the infarcted myocardium, improving ventricular function and long-term survival. Circ Res 97: 663-673, 2005

89. Chmielowiec J, Borowiak M, Morkel M, Stradal T, Munz B, Werner S, Wehland J, Birchmeier C and Birchmeier W: c-Met is essential for wound healing in the skin. J Cell Biol 177: 151-162, 2007.

90. Nicoleau C, Benzakour O, Agasse F, Thiriet N, Petit J, Prestoz L, Roger M, Jaber M and Coronas V: Endogenous hepatocyte growth factor is a niche signal for subventricular zone neural stem cell amplification and self-renewal. Stem Cells 27: 408-419, 2009.

91. De Bacco F, Casanova E, Medico E, Pellegatta S, Orzan F, Albano R, Luraghi P, Reato G, D'Ambrosio A, Porrati P, et al: The MET oncogene is a functional marker of a glioblastoma stem cell subtype. Cancer Res 72: 4537-4550, 2012.

92. Li Y, Li A, Glas M, Lal B, Ying M, Sang Y, Xia S, Trageser D, Guerrero-Cázares H, Eberhart CG, et al: c-Met signaling induces a reprogramming network and supports the glioblastoma stem-like phenotype. Proc Natl Acad Sci USA 108: 9951-9956, 2011.

93. Snuderl M, Fazlollahi L, Le LP, Nitta M, Zhelyazkova BH, Davidson CJ, Akhavanfard S, Cahill DP, Aldape KD, Betensky RA, et al: Mosaic amplification of multiple receptor tyrosine kinase genes in glioblastoma. Cancer Cell 20: 810-817, 2011.

94. Szerlip NJ, Pedraza A, Chakravarty D, Azim M, McGuire J, Fang Y, Ozawa T, Holland EC, Huse JT, Jhanwar S, et al: Intratumoral heterogeneity of receptor tyrosine kinases EGFR and PDGFRA amplification in glioblastoma defines subpopulations with distinct growth factor response. Proc Natl Acad Sci USA 109: 3041-3046, 2012

95. Li C, Wu JJ, Hynes M, Dosch J, Sarkar B, Welling TH, Pasca di Magliano M and Simeone DM: c-Met is a marker of pancreatic cancer stem cells and therapeutic target. Gastroenterology 141: 2218-2227.e5, 2011.

96. Sun S and Wang Z: Head neck squamous cell carcinoma c-Met ${ }^{+}$ cells display cancer stem cell properties and are responsible for cisplatin-resistance and metastasis. Int J Cancer 129: 2337-2348, 2011.

97. van Leenders GJ, Sookhlall R, Teubel WJ, de Ridder CM, Reneman S, Sacchetti A, Vissers KJ, van Weerden W and Jenster G: Activation of c-MET induces a stem-like phenotype in human prostate cancer. PLoS One 6: e26753, 2011.
98. Gastaldi S, Sassi F, Accornero P, Torti D, Galimi F, Migliardi G, Molyneux G, Perera T, Comoglio PM, Boccaccio C, et al: Met signaling regulates growth, repopulating potential and basal cell-fate commitment of mammary luminal progenitors: Implications for basal-like breast cancer. Oncogene 32: 1428-1440, 2013.

99. Miekus K, Lukasiewicz E, Jarocha D, Sekula M, Drabik G and Majka M: The decreased metastatic potential of rhabdomyosarcoma cells obtained through MET receptor downregulation and the induction of differentiation. Cell Death Dis 4: e459, 2013.

100. Skrzypek K, Kusienicka A, Szewczyk B, Adamus T, Lukasiewicz E, Miekus K and Majka M: Constitutive activation of MET signaling impairs myogenic differentiation of rhabdomyosarcoma and promotes its development and progression. Oncotarget 6: 31378-31398, 2015.

101. Miekus K, Pawlowska M, Sekuła M, Drabik G, Madeja Z, Adamek D and Majka M: MET receptor is a potential therapeutic target in high grade cervical cancer. Oncotarget 6: 10086-10101, 2015.

102. Takahashi K and Yamanaka S: Induction of pluripotent stem cells from mouse embryonic and adult fibroblast cultures by defined factors. Cell 126: 663-676, 2006.

103. Jun HJ, Bronson RT and Charest A: Inhibition of EGFR induces a c-MET-driven stem cell population in glioblastoma. Stem Cells 32: 338-348, 2014.

104. Hage C, Rausch V, Giese N, Giese T, Schönsiegel F, Labsch S, Nwaeburu C, Mattern J, Gladkich J and Herr I: The novel c-Met inhibitor cabozantinib overcomes gemcitabine resistance and stem cell signaling in pancreatic cancer. Cell Death Dis 4: e627, 2013.

105. Müller A, Homey B, Soto H, Ge N, Catron D, Buchanan ME, McClanahan T, Murphy E, Yuan W, Wagner SN, et al: Involvement of chemokine receptors in breast cancer metastasis. Nature 410: 50-56, 2001.

106. Zlotnik A, Burkhardt AM and Homey B: Homeostatic chemokine receptors and organ-specific metastasis. Nat Rev Immunol 11: 597-606, 2011.

107. Kucia M, Reca R, Miekus K, Wanzeck J, Wojakowski W, Janowska-Wieczorek A, Ratajczak J and Ratajczak MZ: Trafficking of normal stem cells and metastasis of cancer stem cells involve similar mechanisms: Pivotal role of the SDF-1CXCR4 axis. Stem Cells 23: 879-894, 2005.

108. Phillips TM, McBride WH and Pajonk F: The response of $\mathrm{CD} 24^{-/ 10 w} / \mathrm{CD} 44^{+}$breast cancer-initiating cells to radiation. J Natl Cancer Inst 98: 1777-1785, 2006

109. Martin TA and Jiang WG: Evaluation of the expression of stem cell markers in human breast cancer reveals a correlation with clinical progression and metastatic disease in ductal carcinoma. Oncol Rep 31: 262-272, 2014.

110. Bardelli A, Corso S, Bertotti A, Hobor S, Valtorta E, Siravegna G, Sartore-Bianchi A, Scala E, Cassingena A, Zecchin D, et al: Amplification of the MET receptor drives resistance to anti-EGFR therapies in colorectal cancer. Cancer Discov 3: 658-673, 2013.

111. Turke AB, Zejnullahu K, Wu YL, Song Y, Dias-Santagata D, Lifshits E, Toschi L, Rogers A, Mok T, Sequist L, et al: Preexistence and clonal selection of MET amplification in EGFR mutant NSCLC. Cancer Cell 17: 77-88, 2010.

112. Yano S, Wang W, Li Q, Matsumoto K, Sakurama H, Nakamura T, Ogino H, Kakiuchi S, Hanibuchi M, Nishioka Y, et al: Hepatocyte growth factor induces gefitinib resistance of lung adenocarcinoma with epidermal growth factor receptoractivating mutations. Cancer Res 68: 9479-9487, 2008.

113. Wilson TR, Fridlyand J, Yan Y, Penuel E, Burton L, Chan E, Peng J, Lin E, Wang Y, Sosman J, et al: Widespread potential for growth-factor-driven resistance to anticancer kinase inhibitors. Nature 487: 505-509, 2012

114. Straussman R, Morikawa T, Shee K, Barzily-Rokni M, Qian ZR, Du J, Davis A, Mongare MM, Gould J, Frederick DT, et al: Tumour micro-environment elicits innate resistance to RAF inhibitors through HGF secretion. Nature 487: 500-504, 2012.

115. Luraghi P, Reato G, Cipriano E, Sassi F, Orzan F, Bigatto V, De Bacco F, Menietti E, Han M, Rideout WM III, et al: MET signaling in colon cancer stem-like cells blunts the therapeutic response to EGFR inhibitors. Cancer Res 74: 1857-1869, 2014.

116. Vermeulen L, De Sousa E Melo F, van der Heijden M, Cameron K, de Jong JH, Borovski T, Tuynman JB, Todaro M, Merz $\mathrm{C}$, Rodermond $\mathrm{H}$, et al: Wnt activity defines colon cancer stem cells and is regulated by the microenvironment. Nat Cell Biol 12: 468-476, 2010 
117. Kim KH, Seol HJ, Kim EH, Rheey J, Jin HJ, Lee Y, Joo KM, Lee $\mathrm{J}$ and Nam DH: Wnt/ $\beta$-catenin signaling is a key downstream mediator of MET signaling in glioblastoma stem cells. Neuro Oncol 15: 161-171, 2013.

118. Hashida S, Yamamoto H, Shien K, Miyoshi Y, Ohtsuka T, Suzawa K, Watanabe M, Maki Y, Soh J, Asano H, et al: Acquisition of cancer stem cell-like properties in non-small cell lung cancer with acquired resistance to afatinib. Cancer Sci 106: $1377-1384,2015$.

119. Sugano T, Seike M, Noro R, Soeno C, Chiba M, Zou F, Nakamichi S, Nishijima N, Matsumoto M, Miyanaga A, et al: Inhibition of $\mathrm{ABCB} 1$ overcomes cancer stem cell-like properties and acquired resistance to MET inhibitors in non-small cell lung cancer. Mol Cancer Ther 14: 2433-2440, 2015.
120. Figlin RA, Kaufmann I and Brechbiel J: Targeting PI3K and mTORC2 in metastatic renal cell carcinoma: New strategies for overcoming resistance to VEGFR and mTORC1 inhibitors. Int J Cancer 133: 788-796, 2013

121. Weinstein IB: Cancer. Addiction to oncogenes - the Achilles heal of cancer. Science 297: 63-64, 2002.

122. Sharma SV and Settleman J: Oncogene addiction: Setting the stage for molecularly targeted cancer therapy. Genes Dev 21: 3214-3231, 2007.

123. Viedma-Rodríguez R, Baiza-Gutman L, Salamanca-Gómez F, Diaz-Zaragoza M, Martínez-Hernández G, Ruiz EsparzaGarrido R, Velázquez-Flores MA and Arenas-Aranda D: Mechanisms associated with resistance to tamoxifen in estrogen receptor-positive breast cancer (Review). Oncol Rep 32: 3-15, 2014. 